\title{
Leaf-Gas Exchange of Five Tree Species at Urban Street Sites
}

\author{
Sten Gillner, Sandra Korn, and Andreas Roloff
}

\begin{abstract}
For street trees, site-specific soil and microclimate conditions can restrict growth, health, and longevity for many species. Many urban sites are characterized by a high amount of impervious surface and paved areas resulting in a high rate of surface runoff, low infiltration into soil, and strong reradiation effects. In maintaining the ecologic and economic benefits of street trees through future decades, it is essential to establish species with a high tolerance to stressful urban environments.

Researchers measured leaf-gas exchange of Acer platanoides, Acer pseudoplatanus, Platanus $\times$ hispanica, Quercus rubra, and Tilia platyphyllos to assess stomatal conductance, transpiration, and net photosynthesis at impervious urban sites in the city of Dresden, Germany.

The results show significantly higher leaf-gas exchange rates for the species Platanus $\times$ hispanica and Quercus rubra, compared to the species Acer platanoides and Acer pseudoplatanus. The significantly higher mean values of water-use efficiency of Platanus $\times$ hispanica and Quercus rubra, and in particular the values during the selected periods with a high vapor pressure deficit, indicate more economical water consumption.

Key Words. Acer platanoides; Acer pseudoplatanus; Climate Change; Dresden; Germany; Leaf-Gas Exchange; Platanus $\times$ hispanica; Quercus rubra; Street Trees; Tilia platyphyllos; Urban Trees; Water-Use Efficiency.
\end{abstract}

Knowledge of environmental and climatic tolerance of urban tree species often fades into the background, and aesthetic attributes, tree size, and crown shape play a more important role for planners and landscape designers (Celestian and Martin 2005). But often neglected are the challenging environmental and climatic conditions in urban areas that restrict the growth of many species (Gillner et al. 2013), contradicting the intended appearance and benefits and leading to, for example, leaf discoloration, defoliation, and crown dieback (Roloff et al. 2013).

Many street tree sites are characterized by site, soil, and microclimatic conditions, causing declining vitality and a short life span (Sieghardt et al. 2005; Roloff 2013). In particular, the extent of paving determines degree of infiltration, rate of surface runoff, and further water supply of street trees (Blume 2000; Bhaduri et al. 2001; Conway 2007). Growth and vitality are considerably restricted by microclimatic conditions, such as generally higher air temperatures and lower air humidity caused by reradiation effects, higher surface temperatures, and higher wind spells (tunnel effects) in streets
(Arnfield 2003; Sieghardt et al. 2005; Huang et al. 2008). This urban heat island effect may be advantageous for plants adapted to the hot climates used in temperate and boreal urban areas (Sæbø et al. 2005; Sieghardt et al. 2005), but for most plants and trees used in Central European cities, like Dresden, Germany, these specific soil and climatic terms might induce high levels of water and heat stress.

Further, in Central Europe the problem of water shortage during vegetation period will intensify due to long-term trends, with generally rising average temperatures and more frequent weather extremes, like periods of drought and heat waves (Bernhofer et al. 2009; IPCC 2013). Although projected precipitation amount and distribution is more uncertain than temperature projections (Bernhofer et al. 2009), even under constant precipitation, higher temperatures will increase evaporation and shorten water supply.

Leaf-gas exchange measurements characterize stomatal conductance, transpiration, and net photosynthesis under prevailing climatic conditions at natural sites (Zotz et al. 2005; Morecroft et al. 2008; Stokes et al. 2010; Aasamaa and Sõber 
2011a; Aasamaa and Sõber 2011b). This approach is also gaining increasing importance for urban trees (Kjelgren and Montague 1998; Chunxia et al. 2008; Fini et al. 2009; Leuzinger et al. 2010), in particular to answer questions of species-specific drought tolerance and to use this information for water management, for example (Bush et al. 2008). For planners and managers of urban woodlands and trees, knowledge of species stomatal conductance and transpiration rates, as well as water-use efficiency (wue), may provide essential support for the selection of water-conserving species. Until now there are only few studies assessing gas exchange parameters of mature urban trees, since it is difficult to quantify any physiological reaction of trees to a challenging environment like complex urban conditions. This may be attributed to the difficulties in comparing sites with diverging environmental conditions, as well as how it is linked to specific growth rates, life spans, and management regimes.

The objective of this research was to study five commonly distributed urban tree species concerning leaf-gas exchange at urban sites, as well as species sensitivity to vapor pressure deficit (VPD) and soil moisture of mature trees. In detail, researchers used seasonal measurements of stomatal conductance, transpiration, net photosynthesis, and the water-use efficiency measured during the vegetation periods of two consecutive years for species-specific sensitivity ranking at highly urban street tree sites.

\section{MATERIALS AND METHODS}

\section{Study Site and Species}

The study took place in the city of Dresden, Saxony, Germany, during the summer months in 2009 and 2010. Leaf-gas exchange was measured for the following five species: Acer platanoides L., Acer pseudoplatanus L., Platanus $\times$ hispanica Münchh., Quercus rubra L., and Tilia platyphyllos Scop. Table 1 indicates the number of measured trees per site, the $\mathrm{DBH}$, the height, and the year planted. Acer species were planted in 1914 and all other species in 1920. All trees had been carefully managed over the last decades and did not show any symptoms of damages, injuries, pest, and diseases on trunk and crown (Landeshauptstadt Dresden 2008). This means that only in case of imminent danger for pedestrians, traffic, or other targets, damaged parts of the trees were removed.

All sites are located in residential areas with a building stock of the 19th and early 20th century arranged in classical block development (Landeshauptstadt Dresden 2008). Building heights were comparable, reaching maximum values of $15 \mathrm{~m}$. The trees were planted in strips on the sidewalk along both sides of the street, surrounded by sections of impervious surface and paved areas. The soil types show sandy (loam) to clay-loam substrate with a minimum distance to the mean groundwater table of $3 \mathrm{~m}$ (Table 1). Soil pH-values ranged from 5.8 to 6.9.

Since compaction is a major stress on urban trees (Blume 2000; Bühler et al. 2007), researchers used data and classification of the soil compaction used by Dresden city administration (less compacted, heavily compacted, and not compacted). For this assessment soil structure, bulk density and shearing resistance in 40 to $60 \mathrm{~cm}$ soil depth soil depth in the tree pit was used (Landeshauptstadt Dresden 2008). Except for trees of Acer pseudoplatanus and Tilia platyphyllos with less compacted soil, heavily compacted soil was observed in all other tree pits (Landeshauptstadt Dresden 2008) (Table 1).

Modification of microclimate, runoff, infiltration, soil compaction groundcover, and conditions of pavement strongly affect leaf-gas exchange (Mueller and Day 2005; Roberts et al. 2006). On this account, porosity index of the surface type, according to Blume (2000), was calculated, which describes the permeability of the surface type in crown projection area. The percentage of every surface type (asphalt, grass, gravel-sand mixture, big cobblestone, small cobblestone) in crown projection area was obtained, and the surface-specific porosity index according to Blume (2000) was multiplied with the respective percentage in crown projection area to obtain the mean porosity of the surface under every crown. Mean porosity of the selected sites is comparable and ranges from 0.15 (Quercus rubra) to 0.50 (Tilia platyphyllos).

\section{Climatic Conditions}

The Elbe Valley within the city of Dresden (latitude $51^{\circ} 02^{\prime}$; longitude $13^{\circ} 49^{\prime}$ ) is a metropolitan area located in eastern Germany. The climate is humid-continental, and the longtime averages of the meteorological station Dresden-Klotzsche in- 
Table 1. Tree and site characteristics obtained from city administration (Landeshauptstadt Dresden 2008), and supplemented by surveys in 2010 .

\begin{tabular}{|c|c|c|c|c|c|}
\hline & A. platanoides & A. pseudoplatanus & P. $\times$ hispanica & Q. rubra & T. platyphyllos \\
\hline No. of measured trees & 5 & 4 & 6 & 3 & 4 \\
\hline $\mathrm{DBH}(\mathrm{cm})$ & $48.3 \pm 8.1$ & $47.0 \pm 7.0$ & $85.3 \pm 9.9$ & $32.9 \pm 4.5$ & $40.6 \pm 6.2$ \\
\hline Height (m) & $16.2 \pm 1.2$ & $13.2 \pm 2.2$ & $19.3 \pm 4.0$ & $15.9 \pm 0.7$ & $17.1 \pm 1.2$ \\
\hline Year of planting & 1914 & 1914 & 1920 & 1920 & 1920 \\
\hline Name of the street & Lilienthalstr. & Sachsenwerkstr. & Robert-Berndt-Str. & Robert-Berndt-Str. & Krippenerstr. \\
\hline $\begin{array}{l}\text { Height above mean } \\
\text { sea level (a.s.l.) [m] }\end{array}$ & 119 & $119-120$ & 120 & 120 & 119 \\
\hline $\begin{array}{l}\text { Depth to groundwater } \\
\text { table (Landeshauptstadt } \\
\text { Dresden) [m] }\end{array}$ & $3-6$ & $3-6$ & $3-6$ & $3-6$ & $3-6$ \\
\hline Soil texture & clay-loam & loam & clay-loam & clay-loam & sandy (loam) \\
\hline $\begin{array}{l}\text { Soil compaction } \\
\text { [40-60 cm soil depth] } \\
\text { (Landeshauptstadt Dresden) }\end{array}$ & less & heavily & heavily & heavily & less \\
\hline $\begin{array}{l}\mathrm{pH} \text { value }[30-50 \text { soil } \\
\text { depth] }[ \pm \mathrm{SD}]\end{array}$ & $6.6 \pm 0.48$ & $6.8 \pm 0.32$ & $6.8 \pm 0.18$ & $6.8 \pm 0.41$ & $5.9 \pm 0.15$ \\
\hline $\begin{array}{l}\text { Porosity of the crown } \\
\text { projection area }[ \pm S D]\end{array}$ & $0.40 \pm 0.11$ & $0.35 \pm 0.14$ & $0.35 \pm 0.10$ & $0.15 \pm 0.03$ & $0.50 \pm 0.16$ \\
\hline $\begin{array}{l}\text { Mean unsealed area of } \\
\text { tree pit }\left[\mathrm{m}^{2} \pm \mathrm{SD}\right]\end{array}$ & $3.56 \pm 0.18$ & $2.95 \pm 0.81$ & $3.28 \pm 0.35$ & $1.92 \pm 0.45$ & $2.63 \pm 1.07$ \\
\hline $\begin{array}{l}\text { Renewal of the asphalt } \\
\text { Pavement (Landeshauptstadt } \\
\text { Dresden) [year] }\end{array}$ & 1993 & 1993 & $1995-1996$ & 1995-1996 & $1995^{*}$ \\
\hline
\end{tabular}

dicate a mean annual temperature of $9.2^{\circ} \mathrm{C}$ and precipitation of $663 \mathrm{~mm}$ for the period 1971 to 2000 (all data obtained from DWD 2012). Climate conditions in both years of the study differed from mean conditions 1971-2000. Particularly in year 2010, when precipitation was over $1000 \mathrm{~mm}$, $154 \%$ above the long-term mean (Figure 1). Although precipitation sums from May to August were above-average in both years, temperature records show slightly above-average values, and for June and July in 2010, temperatures, sunshine duration, and relative humidity indicate hot and dry periods over several days (Figure 1). Vapor pressure deficit (VPD, $\mathrm{kPa}$ ) was used for the identification of atmospheric drought, which was calculated using the Magnus equation (Magnus 1844). Two periods with highest VPD values $(\mathrm{VPD}>1.0 \mathrm{kPa})$ were selected to investigate leaf-gas exchange: June 28 to July 4, 2010, and from July 8 to July 14, 2010.

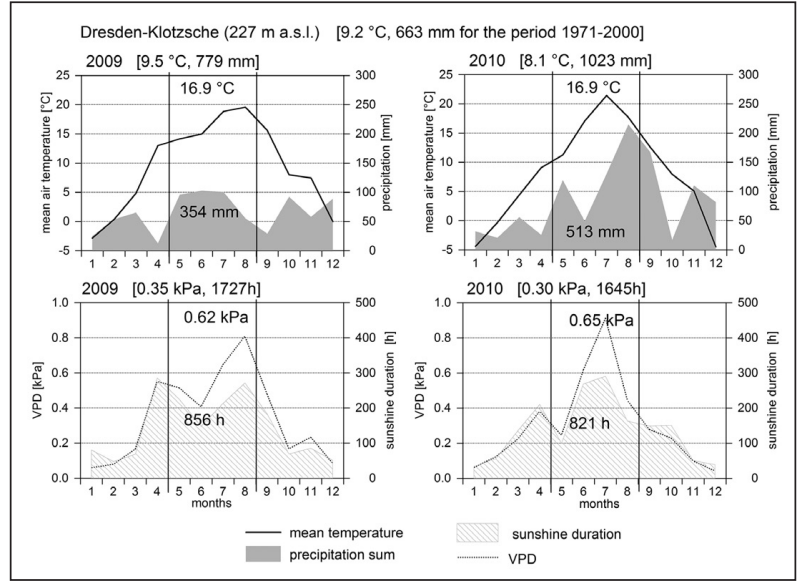

Figure 1. Climatic conditions of the years 2009 and 2010. Mean values of temperature, precipitation, relative humidity, and sunshine duration for the whole years are indicated in the square brackets, and the means from May to August for both years in the diagrams (DWD 2012). 


\section{Volumetric Soil Water Content and Soil Water Potential}

For the year 2010 volumetric soil water content $(\Theta$, Vol.-\%) and soil water potential $\left(\Psi_{\text {soil }}, \mathrm{hPa}\right)$ were measured to compare soil water conditions at the sites during physiological measurements. Two access tubes were installed vertically into the soil at every tree pit to measure $\Theta$ with PR2 soil moisture profile probes at six depths 10, 20, 30, 40, 60, and $100 \mathrm{~cm}$ (Delta-T Devices Ltd, United Kingdom). For $\Psi_{\text {soil }}$ tensiometers (T1S; UP GmbH, Germany) with shafts lengths of $20,40,60,80 \mathrm{~cm}$ were installed in the ground.

\section{Gas Exchange}

Gas exchange rates were measured between 8:00 am and 6:00 pm (CEST, Central European Summer Time) at fixed temperature of $25^{\circ} \mathrm{C}$ with a relative humidity within the chamber of about $40 \%-75 \%$, and at constant photosynthetic photon flux density (PPFD) of $1600 \mu \mathrm{mol} \mathrm{m} \mathrm{s}^{-1}$. Researchers investigated fully expanded, healthy leaves on exposed peripheral twigs in full sun canopy sections in the top one-third of the crowns using a lift. Leaves with signs of fungi and insect pests as well as senescent leaves were excluded from examination. Several leaves of one species were measured during a measuring day. For every species, several replicates were conducted, with a minimum of four. The first replicate was done after all five species had been measured once; the second after all species had been measured two times, and so on. Measurements were conducted during June, July, and August in the years 2009 and 2010 using the portable infrared gas analyzer HCM-1000 (Heinz Walz GmbH, Germany). Before each measurement started, a porometer was calibrated in accordance with the user guidelines (Heinz Walz GmbH, Germany). Under these conditions, net photosynthesis was defined as the maxima or light-saturated net photosynthesis $\left(\mathrm{A}_{\max }\right)$.

To assess efficiency of water use, the wue was calculated from the ratio of $\mathrm{A}_{\max }$ and $\mathrm{E}$ (Larcher 2001).

\section{Statistics}

Statistical analysis was performed with the $\mathrm{R}$ software (R Development Core Team 2008). Data sets were tested for normal distribution using the Shapiro-Wilk-Test $(P \leq 0.05)$ (Shapiro and Wilk 1965). Since data showed no normal distribution, the nonparametric method of Kruskal-Wallis was used to test if distribution of data sets differs. In case of sig- nificant differences Pairwise Mann-Whitney U rank sum test with a Bonferroni correction was applied to localize the differences. Due to the non-normal distribution of datasets, box-and-whisker plots were used to describe gas-exchange data and enabled a clear comparison between species and dates. Plots were created with Xact (Version 8.03, SciLab, Germany).

\section{RESULTS}

\section{Leaf-Gas Exchange}

Figure 2 shows the distribution of transpiration and stomatal conductance in the years 2009 and 2010. Species with high rates of stomatal conductance also have high rates of transpiration. In both years, maxima rates for transpiration up to $2.3 \mathrm{mmol} \mathrm{m}^{-2} \mathrm{~s}^{-1}$ for Platanus $\times$ hispanica and minima values close to zero for Acer pseudoplatanus were measured. Comparing the medians, Acer platanoides had only 33\%, Acer pseudoplatanus $47 \%$, and Tilia platyphyllos $53 \%$ of the transpiration rate of Platanus $\times$ hispanica in the year 2010 . These differences were significant at $P<0.05$.

In 2010, the medians of transpiration as well as stomatal conductance are higher than in 2009 for all species. However, medians of transpiration rates of Acer pseudoplatanus, Platanus $\times$ hispanica, Quercus rubra, and Tilia platyphyllos ranging from 0.80 to $1.25 \mathrm{mmol} \mathrm{m}^{-2} \mathrm{~s}^{-1}$ don't show any significant differences among the species in 2010. Transpiration rate of Acer platanoides with only $37 \%$ of Platanus $\times$ hispanica differed significantly from all other species.

Corresponding to the transpiration rates and stomatal conductance, researchers measured the highest medians ofnet-photosynthesis for Platanus $\times$ hispanica with $4.7 \mu \mathrm{mol} \mathrm{m} \mathrm{m}^{-2} \mathrm{~s}^{-1}$ and for Quercus rubra with $4.5 \mu \mathrm{mol} \mathrm{m} \mathrm{s}^{-1}$ with maxima of more than $8 \mu \mathrm{mol} \mathrm{m}^{-2} \mathrm{~s}^{-1}$ (Figure 2). In contrast to these species showing high rates of net photosynthesis, Acer platanoides has only $21 \%$, Acer pseudoplatanus 37\%, and Tilia platyphyllos $64 \%$ of net photosynthesis of Platanus $\times$ hispanica in 2010. In the year 2009, these differences are even more pronounced with rates of net photosynthesis of only 14\% for Acer platanoides, 23\% for Acer pseudoplatanus, and 25\% for Tilia platyphyllos compared with Platanus $\times$ hispanica. Significant differences of net photosynthesis at $P<0.05$ therefore can be found between the group of Platanus $\times$ hispanica and Quercus rubra and the other trees species (Figure 2). 


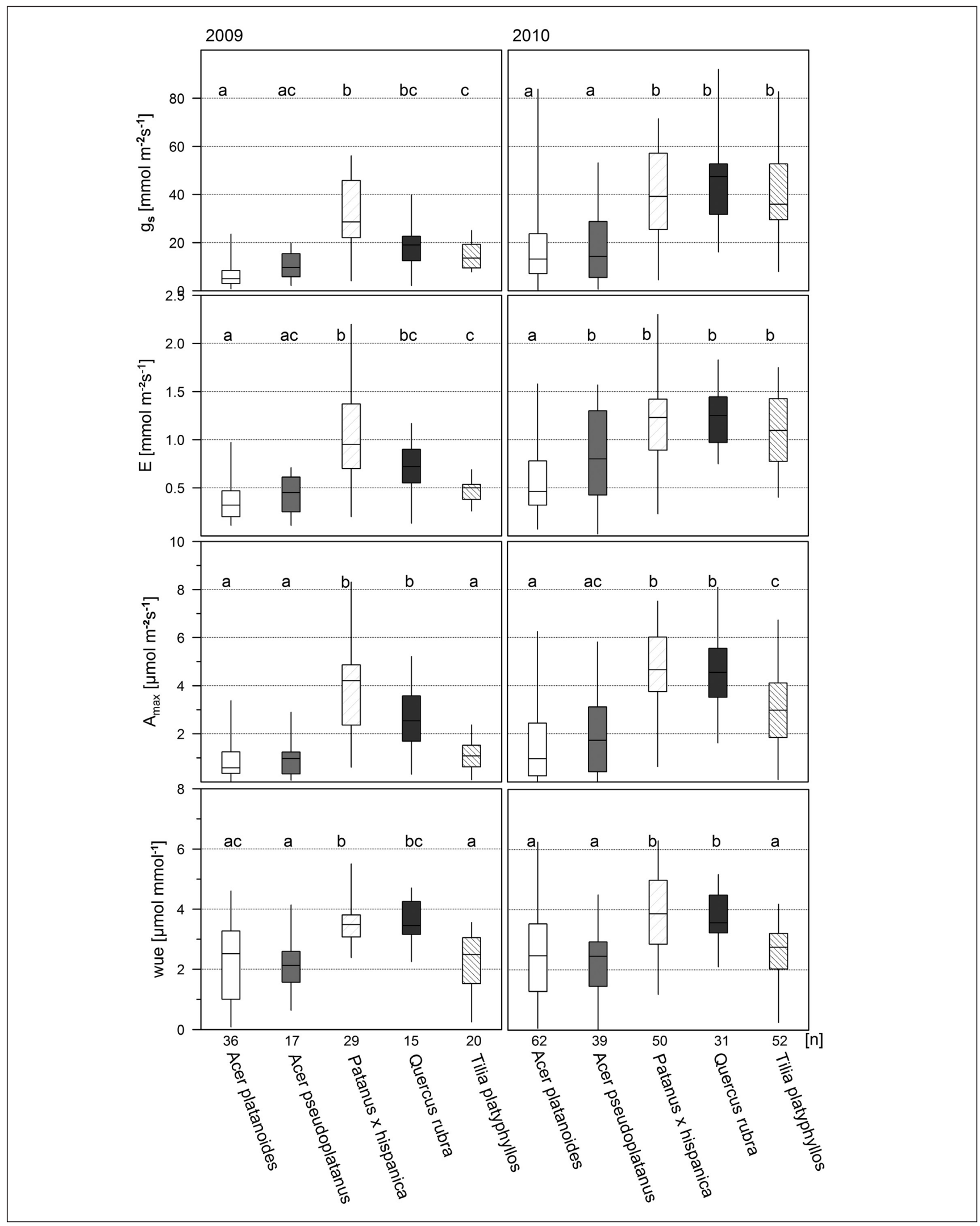

Figure 2. Transpiration rates $(E)$, stomatal conductance $\left(g_{s}\right)$, net photosynthesis $\left(A_{\max }\right)$ and water-use efficiency (wue) in 2009 and 2010. Significant differences $(P<0.05)$ between the species are indicated by different letters. $n=$ number of measurements. 
The study authors calculated for both years highest wue for Platanus $\times$ hispanica and Quercus rubra, with 3.8 and $3.5 \mu \mathrm{mol} \mathrm{mmol}{ }^{-1}$, respectively (Figure 2). In 2010, Acer platanoides, Acer pseudoplatanus, and Tilia platyphyllos showed significantly lower efficiency in the use of the available water expressed in wue rates, down to 1.5 times lower (2.1 to $2.7 \mu \mathrm{mol} \mathrm{mmol}{ }^{-1}$ ) compared with Platanus $\times$ hispanica and Quercus rubra.

\section{Leaf-Gas Exchange Response to VPD and Soil Moisture}

During periods of dry air (VPD > $1.0 \mathrm{kPa})$, gas exchange rates were not reduced, compared with median values of the years 2009 and 2010. The detected differences between the species are true also when considering high VPD values with lowest leaf-gas exchange rates for Acer platanoides and highest rates for Platanus $\times$ hispanica and Quercus rubra (Table 2). Only Tilia platyphyllos showed a somewhat different performance with non-significant differences to Platanus $\times$ hispanica and Quercus rubra for E, $\mathrm{g}_{\mathrm{s}}$, and wue compared with the leaf-gas exchange rates in 2009 and 2010.

The slope of the regression lines and the coefficients of determination indicate different relationships between stomatal conductance and VPD for the species (Figure 3), with a moderate slope for Acer platanoides and Acer pseudoplatanus and the steep slope for Quercus rubra followed by Tilia platyphyllos and Platanus $\times$ hispanica. Thus, below a VPD of $1.5 \mathrm{kPa}$ Acer platanoides and Acer pseudoplatanus show stomatal conductance rates of $14 \mathrm{mmol} \mathrm{m}^{-2} \mathrm{~s}^{-1}$, and $18 \mathrm{mmol} \mathrm{m}^{-2} \mathrm{~s}^{-1}$, respectively, indicating a high sensitivity at lower VPD levels, whereas stomatal conductance of Platanus $\times$ hispanica and Quercus rubra with $39 \mathrm{mmol} \mathrm{m}^{-2} \mathrm{~s}^{-1}$ and $41 \mathrm{mmol} \mathrm{m}^{-2} \mathrm{~s}^{-1}$, respectively, is more than double that of Acer species. As $\mathrm{VPD}$ increases of $2.0 \mathrm{kPa}$ stomatal conductance ranges from $4.2 \mathrm{mmol} \mathrm{m}^{-2} \mathrm{~s}^{-1}$ for Acer platanoides to $20.0 \mathrm{mmol} \mathrm{m} \mathrm{m}^{-2} \mathrm{~s}^{-1}$ for Platanus $\times$ hispanica. Under an increasing VPD, Quercus rubra has the strongest decreasing stomatal conductance of all species (Figure 3). Relationship with $\mathrm{R}^{2}=0.21$ between VPD and stomatal conductance for Acer pseudoplatanus and Tilia platyphyllos is small.

Significant differences between the sites as well as among soil depths can be found (Figure 4). The low-

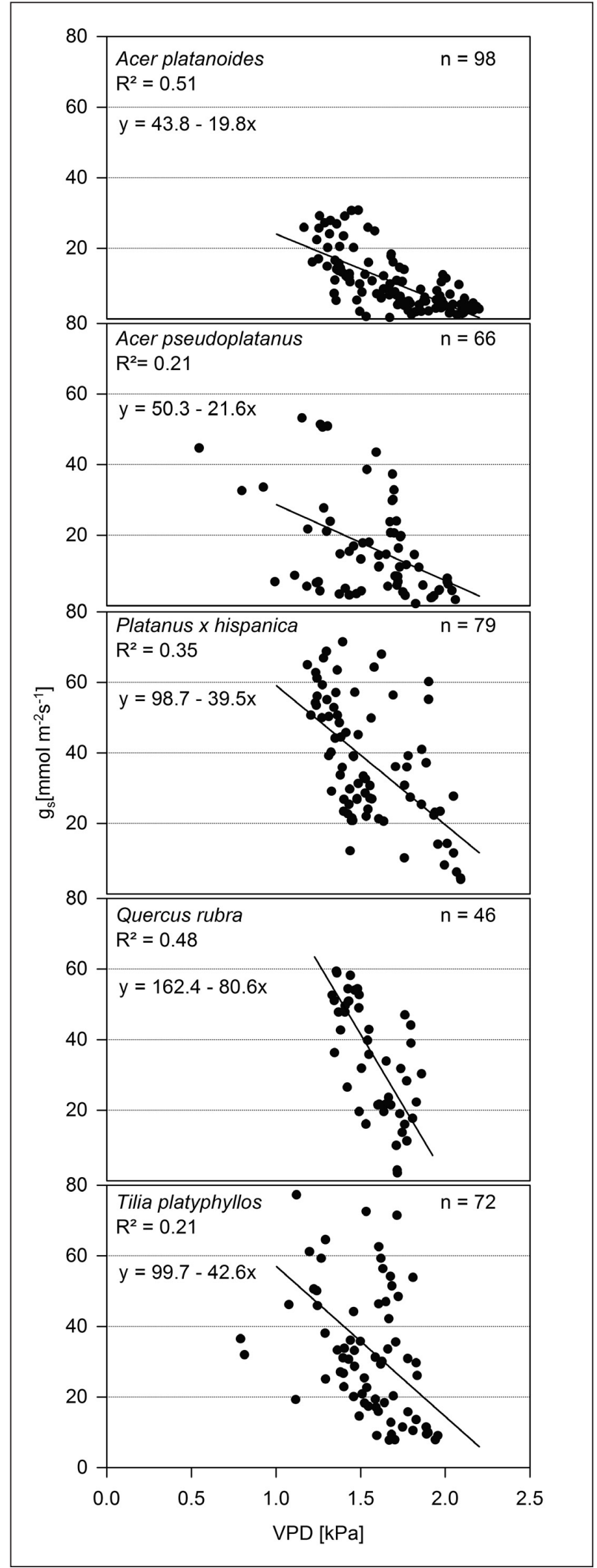

Figure 3. Relationships between VPD and $\mathbf{g}_{\mathrm{s}}$ over all values for both years (2009 and 2010). Number of measurements is indicated by $n$ and coefficient of determination for the regression by $R^{2}$. All regressions are significant at $P<0.05$. 
Table 2. Medians of transpiration (E), stomatal conductance $\left(g_{s}\right)$, net photosynthesis $\left(A_{\max }\right)$, and water-use efficiency (wue), and their standard deviations during periods of dry air (VPD $>1.0 \mathrm{kPa})$. Significant differences $(P<0.05)$ between the species are indicated by different letters. $\mathrm{n}=$ number of measurements.

\begin{tabular}{lrlll}
\hline Species & $\mathrm{n}$ & $\begin{array}{l}\mathrm{E} \\
{\left[\mathrm{mmol} \mathrm{m}^{-2} \mathrm{~s}^{-1}\right]}\end{array}$ & $\begin{array}{l}\mathrm{g}_{\mathrm{s}} \\
{\left[\mathrm{mmol} \mathrm{m}^{-2} \mathrm{~s}^{-1}\right]}\end{array}$ & $\begin{array}{l}\mathrm{A}_{\max } \\
{\left[\mu \mathrm{mol} \mathrm{m}^{-2} \mathrm{~s}^{-1}\right]}\end{array}$ \\
\hline A. platanoides & 27 & $0.60 \pm 0.29 \mathrm{a}$ & $16.6 \pm 11.0 \mathrm{a}$ & $1.41 \pm 1.25 \mathrm{a}$ \\
A. pseudoplatanus & 19 & $1.15 \pm 0.46 \mathrm{~b}$ & $32.6 \pm 15.2 \mathrm{ab}$ & $2.97 \pm 1.49 \mathrm{ac}$ \\
P. $\times$ hispanica & 13 & $1.37 \pm 0.42 \mathrm{~b}$ & $50.7 \pm 14.8 \mathrm{~b}$ & $5.66 \pm 1.28 \mathrm{~b}$ \\
Q. rubra & 8 & $1.18 \pm 0.29 \mathrm{~b}$ & $34.1 \pm 10.7 \mathrm{~b}$ & $4.29 \pm 0.85 \mathrm{bc}$ \\
T. platyphyllos & 24 & $1.33 \pm 0.37 \mathrm{~b}$ & $37.3 \pm 16.8 \mathrm{~b}$ & $3.85 \pm 1.26 \mathrm{~b}$ \\
\hline
\end{tabular}

Table 3. Medians of transpiration (E), stomatal conductance $\left(g_{s}\right)$, net photosynthesis $\left(A_{\max }\right)$, and water-use efficiency (wue), and their standard deviations during periods of edaphic drought from June 25 to July 2, 2010, and from July 12 to July 21,2010 . Significant differences $(P<0.05)$ between the species are indicated by different letters. $n=$ number of measurements.

\begin{tabular}{lllll}
\hline Species & $\mathrm{n}$ & $\begin{array}{l}\mathrm{E} \\
{\left[\mathrm{mmol} \mathrm{m}^{-2} \mathrm{~s}^{-1}\right]}\end{array}$ & $\begin{array}{l}\mathrm{g}_{\mathrm{s}} \\
{\left[\mathrm{mmol} \mathrm{m}^{-2} \mathrm{~s}^{-1}\right]}\end{array}$ & $\begin{array}{l}\mathrm{A} \text { max } \\
{\left[\mu \mathrm{mol} \mathrm{m}^{-2} \mathrm{~s}^{-1}\right]}\end{array}$ \\
\hline A. platanoides & 36 & $0.67 \pm 0.19 \mathrm{a}$ & $17.5 \pm 4.0 \mathrm{a}$ & $1.94 \pm 0.78 \mathrm{a}$ \\
A. pseudoplatanus & 21 & $0.98 \pm 0.47 \mathrm{ab}$ & $23.9 \pm 15.8 \mathrm{a}$ & $2.42 \pm 1.57 \mathrm{a}$ \\
$P . \times$ hispanica & 13 & $1.39 \pm 0.50 \mathrm{~b}$ & $39.2 \pm 15.8 \mathrm{~b}$ & $4.94 \pm 1.65 \mathrm{~b}$ \\
Q. rubra & 4 & $1.18 \pm 0.30 \mathrm{ab}$ & $31.1 \pm 8.0 \mathrm{ab}$ & $3.36 \pm 1.26 \mathrm{ab}$ \\
T. platyphyllos & 16 & $1.00 \pm 0.35 \mathrm{~b}$ & $33.9 \pm 18.0 \mathrm{ab}$ & $2.59 \pm 0.88 \mathrm{a}$ \\
\hline
\end{tabular}

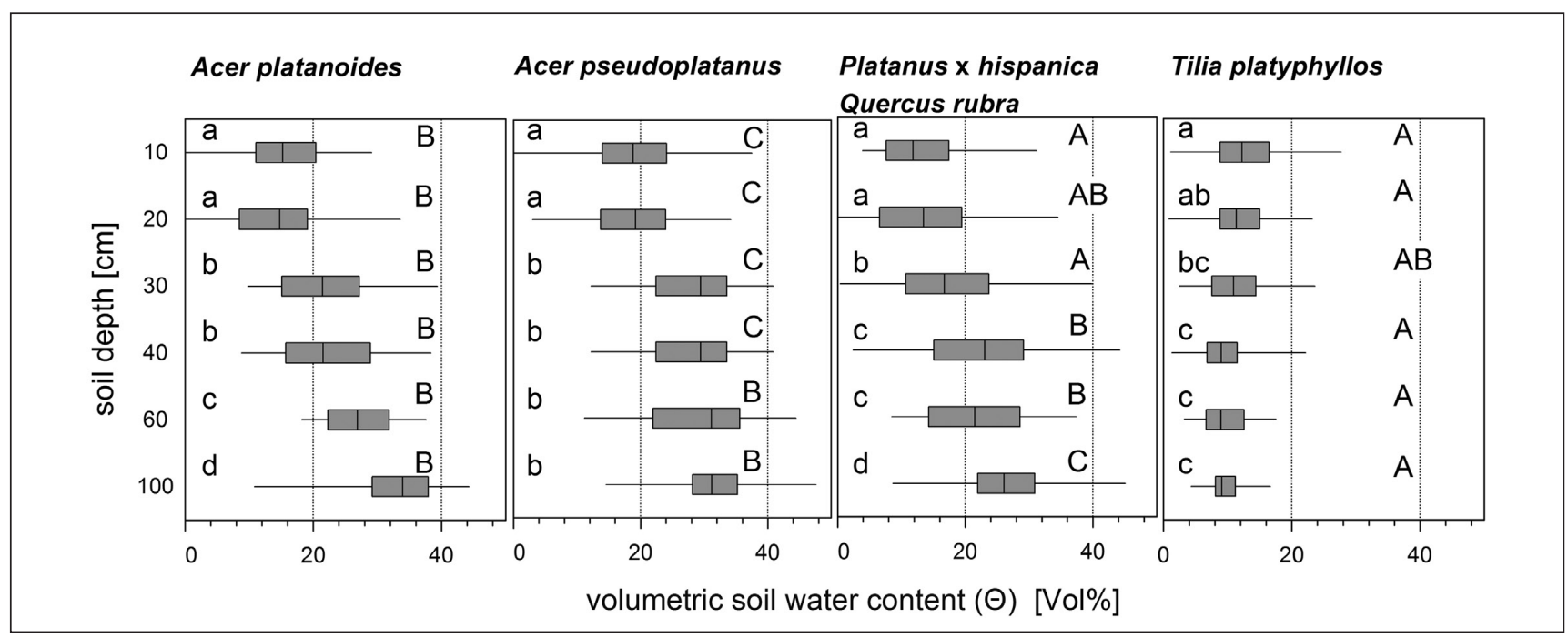

Figure 4. Means of volumetric soil water content $(\Theta)$ in six soil depths. Small letters indicate significant differences between the $\Theta$ of soil depths for one site and big letters between the different sites (Mann-Whitney U rank sum test with a Bonferroni correction). Since no differences were found between the sites of Platanus × hispanica and Quercus rubra, data were merged into one field.

est mean values of $\Theta$, which always remained below 16 Vol.-\%, were found at the sandy (loamy) site for Tilia platyphyllos, whereas all remaining tree sites showed higher mean values up to 32 Vol.-\%. Except for the site of Tilia platyphyllos with decreasing medians, $\Theta$ increases in deeper soil depths (Figure 2).

The two periods with lowest values of $\Theta$ and $\Psi_{\text {soil }}$ from June 25 to July 2, 2010, and from July 12 to July 21 were used to assess leaf-gas exchange under changed soil moisture conditions. Figure 5 demonstrates the temporal dynamics of $\Theta$ and $\Psi_{\text {soil }}$ at the site where Acer platanoides was growing. An increase in VPD (indicated in light gray bars, periods with highest VPD) was accompanied by a decline in $\Theta$ and $\Psi_{\text {soil }}$ (indicated in dark gray bars) down to the soil depth of $100 \mathrm{~cm}$.

Even during these periods with lowered soil water availability, all tree species showed no reduction in leaf-gas exchange rates (Table 3). Transpiration rates of Acer pseudoplatanus, Platanus $\times$ hispanica, Quercus rubra, and Tilia platyphyllos were around twice 
as high as rate of Acer platanoides. Considering $\mathrm{CO}_{2}-$ uptake rates, Acer platanoides has only 25\% and Acer pseudoplatanus has only $52 \%$ of the rates of Platanus $\times$ hispanica. In the selected periods of low soil moisture condition, species nevertheless showed very similar values of wue between 2.5 to $2.9 \mu_{\mathrm{mol} \mathrm{mmol}}{ }^{-1}$ without significant differences among the species.

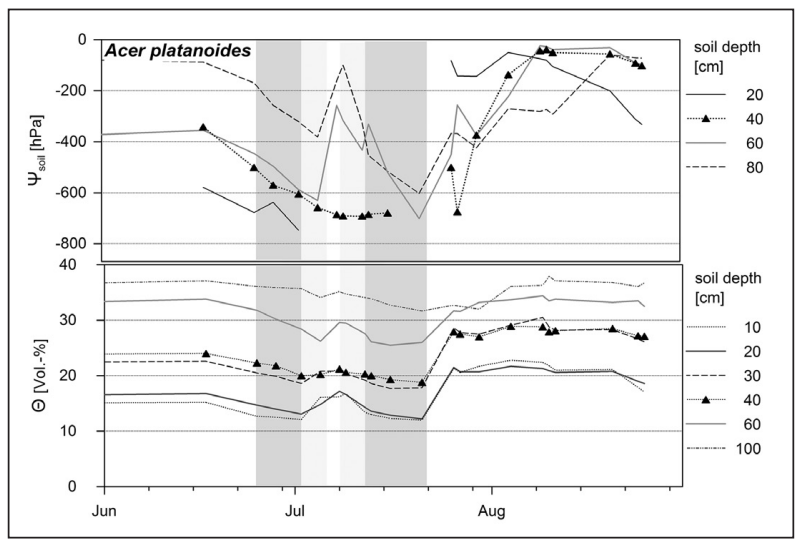

Figure 5. Seasonal scale of soil water content $(\Theta)$ and soil water potential $\left(\Psi_{\text {soil }}\right)$ from January 6 to August 31, 2010 ( $n=$ 21 measurements). Indicated are the means of the measurements of the site. Vertical light gray bars indicate periods with VPD $>1.0 \mathrm{kPa}$, and dark gray bars periods of lowest soil moisture conditions.

\section{DISCUSSION}

\section{Site and Environmental Conditions During Measurements}

Homogeneous microclimatic, edaphic and growth environments are prerequisites for comparing species-specific physiological traits (Larcher 2001; Ferrini and Baietto 2006; Fini et al. 2009; Stokes et al. 2010; Aasamaa and Sõber 2011a;). The tree pits showed comparable degree of impervious surface and $\mathrm{pH}$ values, indicating a slightly acidic to neutral soil (Table 1). Except the site for Acer platanoides and Tilia platyphyllos, which had less compacted soil, all other sites showed heavily compacted soil condition. Despite of the more favorable conditions for root development and water uptake (Roberts et al. 2006), both species did not take advantage of the lower soil compaction and even showed lower leafgas exchange rates compared with Platanus $\times$ hispanica and Quercus rubra. Soil texture and volumetric soil water contents show similar values except for the site for Tilia platyphyllos, which had sandier and drier soil conditions (Table 1; Figure 4). Since the studied sites did not differ in building heights and building structure, the relative low leaf-gas exchange rates can be regarded as species-specific response to the environmental conditions at the urban sites (Kjelgren and Montague 1998; Cregg and Dix 2001; Montague and Kjelgren 2004; Bartens et al. 2009).

Forrai et al. (2012) reported just as low values of photosynthesis rates $\left(3.68-13.03 \mu \mathrm{mol} \mathrm{m}^{-2} \mathrm{~s}^{-1}\right)$ and correspondingly limited transpiration rates (0.85-2.65 $\left.\mathrm{mmol} \mathrm{m}^{-2} \mathrm{~s}^{-1}\right)$ for ten different urban tree species, like Acer pseudoplatanus, Acer platanoides, Tilia cordata, and others. However, the low level of leaf-gas exchange rates may be a result of the high value of PPFD resulting in photoinhibition (Pollastrini et al. 2013), and reducing the capacity to convert solar energy to electron transport (Takahashi and Murata 2008). The variable light regime in mixed forests leads to a wide range of light adaptation, and low values of PPFD may already induce photoinhibition (Pollastrini et al. 2013). At the urban tree sites, exposure to light is very high and crowns are more sun-exposed compared to forest trees. As a consequence, a higher amount of sun-adapted leaves form (Lichtenthaler et al. 1981). Sun-adapted leaves are characterized by higher leaf thickness, leaf area, stomatal density, and differ in chlorophyll a and b content leading to a higher light saturation, and light compensation point compared to shade leaves and show maximum rates of net photosynthesis at a high level of PPFD (Lichtenthaler et al. 1981). However, in further studies the species-specific level of photoinhibition should be taken into account.

Seasonal changes with higher leaf-gas exchange rates in spring and declining rates through summer drought can be observed in regions with a typical drought period during summer-e.g., in regions with Mediterranean climate, like California, U.S. (Goulden 1996). In the current study, leaf-gas exchange rates showed only slightly changing values over the growing season (data not shown). That may be due to balanced climatic conditions during the summer months of the years 2009 and 2010 without long-lasting periods of a high levels of VPD or low levels of soil moisture. Although a decline in soil moisture conditions can be observed over the measuring period for all sites in 2010 (c.f. Figure 5), the values of $\Theta$ in 100 $\mathrm{cm}$ soil depth never dropped down to less than 
$25 \mathrm{Vol}-\%, \Psi_{\text {soil }}$ in the soil depth $80 \mathrm{~cm}$ was never below $-700 \mathrm{~h}$. Only for the site of Tilia platyphyllos the soil moisture regime was generally drier, resulting in lower leaf-gas exchange at dry sites.

\section{Species Specific Leaf-Gas Exchange}

Deciduous tree species originating from temperate forests show a low level of stomatal conductance, transpiration, and high leaf surface temperatures at highly paved sites (Kjelgren and Montague 1998). Isolated trees over asphalt intercept more longwave radiation due to higher surface temperatures, resulting in higher water loss on warm summer days and an early closure of stomata (Kjelgren and Montague 1998, Mueller and Day 2005), in particular of Acer platanoides (Kjelgren and Montague 1998). Forrai et al. (2012) reported just as low values of photosynthesis rates (3.68-13.03

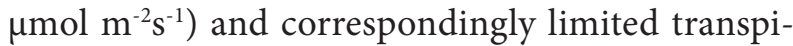
ration rates $\left(0.85-2.65 \mathrm{mmol} \mathrm{m}^{-2} \mathrm{~s}^{-1}\right)$ for ten different urban tree species, like Acer pseudoplatanus, Acer platanoides, Tilia cordata, and others.

Measurements in sun canopy leaves of adult street trees revealed significant differences in leafgas exchange and wue among the species calculated for the total of measurements. In both years 2009 and 2010, $A_{\max }$ rates of Platanus $\times$ hispanica and Quercus rubra reached at least the double of mean $\mathrm{A}_{\max }$ rates of Acer platanoides and Acer pseudoplatanus. Tilia platyphyllos reached approximately $70 \%$ of the $A_{\max }$ of rate of Platanus $\times$ hispanica.

Despite having a higher water use indicated by the higher transpiration rates, results for Platanus $\times$ hispanica and Quercus rubra indicate significant higher mean water-use efficiency. Therefore, these two species may be better adapted, and the species with lower water-use efficiencies may be lower adapted under the prevailing environmental and climatic conditions at the urban sites.

Even under irrigation, down regulation of stomatal conductance leads to decreased transpiration, net photosynthesis, as well as stem sap flow for Acer platanoides in periods with heat and drought (Bush et al. 2008). Although not on a significant level, plot plants of Acer platanoides restricted $\mathrm{g}_{\mathrm{s}}, \mathrm{A}_{\max }$, and $\mathrm{E}$ under reduced irrigation (Fini et al. 2008). Here, lowest values of gas exchange were measured for Acer platanoides, but with no further reduction in the selected periods. Reasons for this may include sufficient soil water supply even during periods with lower soil moisture (at this site constantly over 25 Vol.-\% in $60 \mathrm{~cm}$ soil depth) and ostensibly inherent low gas-exchange rates that resulted in no further reduction. However, physiological behavior of Acer platanoides depends on cultivar and degree of water stress (Fini et al. 2009), particularly at paved urban sites (Kjelgren and Montague 1998). Mean values of wue here were quite similar to that of the cultivar 'Summershade', with a higher susceptibility for drought stress compared to the cultivars 'Deborah' and 'Emerald Queen' (Fini et al. 2009). Physiological traits of Acer platanoides (Aasamaa and Sõber 2011a; Aasamaa and Sõber 2011b) and of Acer pseudoplatanus (Köcher et al. 2009) show sensitive stomatal regulation. A strong relationship of stomatal conductance and VPD was confirmed in the current study for Acer platanoides only $\left(\mathrm{R}^{2}=0.51\right)$, whereas relationship for Acer pseudoplatanus is weak $\left(\mathrm{R}^{2}=0.21\right)$. A high level of soil water supply is essential for optimal leaf-gas exchange for Acer pseudoplatanus (Köcher et al. 2009; Scherrer et al. 2011). However, somewhat contradictory results from Fini et al. (2008) found values of $\mathrm{A}_{\max }$ up to $4.93 \mu \mathrm{mol} \mathrm{m} \mathrm{s}^{-1} \mathrm{~s}^{-1}$ under restricted irrigation (Fini et al. 2008). In general, though, Acer pseudoplatanus is generally ranked to be drought sensitive (Morecroft et al. 2008; Köcher et al. 2009; Hemery et al. 2010; Scherrer et al. 2011).

Tilia platyphyllos is ranked less drought sensitive than Acer platanoides (Fini et al. 2009), which is consistent with current findings of higher wue and gas exchange in Tilia under dryer soil. Adult forest trees of Tilia platyphyllos, however, have been reported to decrease stomatal conductance five-fold during drought, indicating Tilia platyphyllos' drought sensitivity (Leuzinger et al. 2005). This study has also showndecreasingstomatalconductance withincreasing VPD, indicating a sensitive reaction of Tilia.

By contrast, Platanus $\times$ hispanica, among eight species in Warsaw, Poland, was reported to be the most tolerant of stressful urban conditions (Swoczyna et al. 2010), able to maintain greater conductance and wue than other species (Chunxia et al. 2008). Similarly, Leuzinger et al. (2010) found almost twice the stomatal conductance of Tilia platyphyllos and Acer platanoides under balanced water supply. The current study is consistent with these results, since leaf-gas exchange and wue for 
Platanus $\times$ hispanica indicate a more efficient use of water at urban sites remaining also high in the selected periods of a high VPD and low soil moisture.

In dry years, forest trees of Quercus rubra experience minimal decline in net photosynthesis rate compared with wet years in Massachusetts, U.S. (Cavander-Bares and Bazzaz 2000), indicating a high tolerance to drought. The relatively stable transpiration rates under an increasing vapor pressure deficit support these findings for urban trees in Utah, U.S. (Bush et al. 2008). In the current study, Quercus rubra $\mathrm{g}_{\mathrm{s}}$ decreased rapidly with increasing VPD as indicated by the highest slope of regression-80.4 (Figure 3). Quercus rubra also showed higher sensitivity to environmental stressors at urban sites, such as drought and salt, compared with Platanus $\times$ hispanica, but it appears to be less sensitive to drought events than Tilia cordata and Tilia $\times$ vulgaris (Swoczyna et al. 2010).

\section{CONCLUSION}

The findings demonstrate clear differences in stomatal conductance and leaf-gas exchange of five urban tree species. Under comparable soil and microclimatic conditions and in accordance with literature, researchers were able to classify the five selected tree species with regard to their tolerance to the specific site conditions in urban streets as well as their response of gas exchange to VPD and soil moisture.

Mean water-use efficiency of Platanus $\times$ hispanica and Quercus rubra is higher compared with Acer species and Tilia platyphyllos, and allows classifying them as less likely to be restricted by environmental conditions at urban sites. The other tree species show lower water-use efficiencies under the prevailing urban conditions. The species-specific differences in leaf-gas exchange are also true in the selected periods of high VPD and low soil moisture. Tilia platyphyllos differed slightly due to drier soil conditions at their site. Nevertheless, the findings enable a classification of this species, too. It can be found between the group consisting of Acer platanoides and Acer pseudoplatanus, and the group of Platanus $\times$ hispanica and Quercus rubra.

This ranking should not, however, mean that greenspace management must use species adapted to the harsh urban environments exclusively, since a high biodiversity of trees and shrubs is one important long-term strategy to minimize negative biotic and abiotic effects from climate change. Rather, these results can inform consideration of suitable urban sites that correspond best with species habitat and climate/soil preferences. Thus, species reacting, sensitive under the prevailing urban conditions, in this case both Acer species, might be used for shady, north-exposed streets with balanced soil moisture regimes.

Acknowledgments. The authors would like to thank Mr. Alexander Solger and Mr. Erik Fritzsche for their field assistance in sample collection, thank Dr. Juliane Vogt for kindly correcting the paper. We extend our thanks to the staff members of offices for Municipal Affairs (Amt für Stadtgrün und Abfallwirtschaft Dresden), and in particular Mr. Steffen Löbel, for their administrative support, helpful information, and logistic maintenance during the fieldwork. We also want to extend our acknowledgments to the three anonymous reviewers of our manuscript for their useful and helpful comments.

This study was realized with the financial support by the Bundesministerium für Bildung und Forschung (BMBF) in the project REGKLAM (Grant number: 01 LR 0802).

\section{LITERATURE CITED}

Aasamaa, K., and A. Sõber. 2011a. Stomatal sensitivities to changes in leaf water potential, air humidity, $\mathrm{CO} 2$ concentration and light intensity, and the effect of abscisic acid on the sensitivities in six temperate deciduous tree species. Environmental and Experimental Botany 71:72-78.

Aasamaa, K., and A. Sõber. 2011b. Responses of stomatal conductance to simultaneous changes in two environmental factors. Tree Physiology 31:855-864.

Arnfield, A.J. 2003. Two decades of urban climate research: A review of turbulence, exchanges of energy and water, and the urban heat island. International Journal of Climatology 23:1-26.

Bartens, J., S. Day, J. Harris, T. Wynn, and J. Dove. 2009. Transpiration and root development of urban trees in structural soil stormwater reservoirs. Environmental Management 44:646-657.

Bernhofer, C., J. Matschullat, and A. Bobeth. 2009. Das Klima in der REGKLAM-Modelregion Dresden. Regklam Publikationsreihe Heft 1, Rhombos, Berlin, Germany. 117 pp.

Bhaduri, B., M. Minner, S. Tatalovich, and J. Harbor. 2001. Long-term hydrologic impact of urbanization: A tale of two models. Journal of Water Resources Planning and Management 127:13-19.

Blume, H.-P. 2000. Böden städtisch-industrieller Verdichtungsräume. pp. 154-171. In: H-P. Blume, P. Felix-Henningsen, W.R. Fischer, H.G. Frede, R. Horn, and K. Stahr (Eds.). Handbuch der Bodenkunde. Ecomed, Landsberg, Germany.

Bühler, O., P. Kristoffersen, and S.U. Larsen. 2007. Growth of street trees in Copenhagen with emphasis on the effect of different establishment concepts. Arboriculture \& Urban Forestry 33:330-337.

Bush, S.E., D.E. Pataki, K.R. Hultine, A.G. West, J.S. Sperry, and J.R. Ehleringer. 2008. Wood anatomy constrains stomatal responses to atmospheric vapor pressure deficit in irrigated, urban trees. Oecologia 156:13-20.

Cavander-Bares, J., and F.A. Bazzaz. 2000. Changes in drought response strategies with ontogeny in Quercus rubra: Implications for scaling from seedlings to mature trees. Oecologia 124:8-18. 
Celestian, S.B., and C.A. Martin. 2005. Effects of parking lot location on size and physiology of four southwestern U.S. landscape trees. Arboriculture \& Urban Forestry 31:191-197.

Chunxia, H., L. Jiyue, G. Ming, W. Yutao, and C. Chong. 2008. Changes in leaf photosynthetic characteristics and water use efficiency along with tree height of four tree species. Acta Ecologica Sinica 28:3008-3016.

Conway, T.M. 2007. Impervious surface as an indicator of $\mathrm{pH}$ and specific conductance in the urbanizing coastal zone of New Jersey, USA. Journal of Environmental Management 85:308-316.

Cregg, B.M., and M.E. Dix. 2001. Tree moisture stress and insect damage in urban areas in relation to heat island effects. Arboriculture \& Urban Forestry 27:8-17.

DWD (Deutscher Wetterdienst). 2012. Accessed 04/12/2012. $<$ www.dwd.de $>$

Ferrini, F., and M. Baietto, M. 2006. Response to fertilization of different tree species in the urban environment. Arboriculture \& Urban Forestry 32:93-99.

Fini, A., F. Ferrini, P. Frangi, G. Amoroso, and R. Piatti. 2009. Withholding irrigation during the establishment phase affected growth and physiology of Norway maple (Acer platanoides) and linden (Tilia spp.). Arboriculture \& Urban Forestry 35:241-251.

Fini, A., G.B. Mattiiand, and F. Ferrini. 2008. Physiological responses to different irrigation regimes for shade trees grown in container. Advances in Horticultural Science 22:13-20.

Forrai, M., M. Sütöriné Diószegi, M. Ladányi, P. Honfi, and K. Hrotkó. 2012. Studies on estimation of leaf gas exchange of ornamental woody plant species. Applied Ecology and Environmental Research 10:195-206.

Gillner, S., J. Vogt, and A. Roloff. 2013. Climatic response and impacts of drought on oaks at urban and forest sites. Urban Forestry \& Urban Greening 12:597-605.

Goulden, M.L.1996. Carbon assimilation and water-use-efficiency by neighboring Mediterranean-climate oaks that differ in water access. Tree Physiology 16:417-424.

Hemery, G.E., J.R. Clark, E. Aldinger, H. Claessens, M.E. Malvolti, E. O'Connor, Y. Raftoyannis, P.S. Savill, and R. Brus. 2010. Growing scattered broadleaved tree species in Europe in a changing climate: A review of risks and opportunities. Forestry 83:65-81.

Huang, L., J. Li, D. Zhao, and J. Zhu. 2008. A fieldwork study on the diurnal changes of urban microclimate in four types of ground cover and urban heat island of Nanjing, China. Building and Environment 43:7-17.

IPCC (Intergovernmental Panel on Climate Change). 2013. Climate Change 2013. The Physical Science Basis. Working Group I Report to the Fifth Assessment Report of the Intergovernmental Panel on Climate Change, Genf. <www. climatechange2013.org/images/uploads/WGIAR5_WGI12Doc2b_FinalDraft_All.pdf>

Kjelgren, R., and T. Montague. 1998. Urban tree transpiration over turf and asphalt surfaces. Atmospheric Environment 32:35-41.

Köcher, P., T. Gebauer, V. Horna, and C. Leuschner. 2009. Leaf water status and stem xylem flux in relation to soil drought in five temperate broad-leaved tree species with contrasting water use strategies. Annals of Forest Sciences 66:1-11.

Landeshauptstadt Dresden. 2008. Straßenbaumkataster Dresden (database for street trees). Accessed 11/11/2008.

Larcher, W. 2001. Ökophysiologie der Pflanzen. - Leben, Leistung und Stressbewältigung der Pflanzen in ihrer Umwelt. Ulmer, Stuttgart, Germany. 408 pp.
Leuzinger, S., G. Zotz, R. Asshoff, and C. Körner. 2005. Responses of deciduous forest trees to severe drought in Central Europe. Tree Physiology 25:641-650.

Leuzinger, S., R. Vogt, and C. Körner. 2010. Tree surface temperature in an urban environment. Agricultural and Forest Meteorology 150:56-62.

Lichtenthaler, H.K., C. Buschmann, M. Döll, H.J. Fietz, T. Bach, U. Kozel, D. Meier, and U. Rahmsdorf. 1981. Photosynthetic activity, chloroplast ultrastructure, and leaf characteristics of highlight and low-light plants and of sun and shade leaves. Photosynthesis Research 2:115-141.

Magnus, G. 1844. Versuche über die Spannkräfte des Wasserdampfes. Annalen der Physik und Chemie 2:225-247.

Montague, T., and R. Kjelgren. 2004. Energy balance of six common landscape surfaces and the influence of surface properties on gas exchange of four containerized tree species. Scientia Horticulturae 100:229-249.

Morecroft, M.D., V.J. Stokes, M.E. Taylor, and J.I.L. Morison. 2008. Effects of climate and management history on the distribution and growth of sycamore (Acer pseudoplatanus L.) in southern British woodland in comparison to native competitors. Forestry 81:59-74.

Mueller, E.C., and T.A. Day. 2005. The effect of urban ground cover on microclimate, growth, and leaf gas exchange of oleander in Phoenix, Arizona. International Journal of Biometeorology 49:244-255.

Pollastrini, M., V. Holland, W. Brüggemann, J. Koricheva, I. Jussila, et al. 2013. Interactions and competition processes among tree species in young experimental mixed forests, assessed with chlorophyll fluorescence and leaf morphology. Plant Biology 16:1-9.

Roberts, J., N. Jackson, and M. Smith. 2006. Tree Roots in the Built Environment. The Stationery Office, Norwich, England. 488 pp.

Roloff, A. 2013. Verwendung von Baumarten in der Stadt. pp. 30-44. In: A. Roloff (Eds.). 2013. Bäume in der Stadt. Ulmer, Stuttgart, Germany.

Roloff, A., B. Grundmann, and S. Korn. 2013. Trockenstress: Ursachen und Konsequenzen für Stadtbäume. pp. 187-201. In: A. Roloff (Ed.). Bäume in der Stadt. Ulmer, Stuttgart, Germany.

Sæbø, A., B. Zelimir, C. Ducatillion, A. Hatzistathis, T. Lagerström, et al. 2005. The selection of plant materials for street trees, park trees and urban woodlands. pp. 257-280. In: C.C. Konijnendijk, K. Nilsson, T.B. Randrup, and J. Schipperijn (Eds.). Urban Forests and Trees. Springer, Berlin, Germany.

Scherrer, D., M.K. Bader, and C. Körner. 2011. Drought-sensitivity ranking of deciduous tree species based on thermal imaging of forest canopies. Agricultural and Forest Meteorology 151:16321640.

Shapiro, S.S., and M.B. Wilk. 1965. An Analysis of Variance Test for Normality (Complete Samples). Biometrika 52:591-611.

Sieghardt, M., E. Mursch-Radlgruber, E. Paoletti, E. Couenberg, et al. 2005. The abiotic urban environment: Impact of urban growing conditions on urban vegetation. pp. 281-323. In: C.C. Konijnendijk, K. Nilsson, T.B. Randrup, and J. Schipperijn (Eds.). Urban Forests and Trees. Springer, Berlin, Germany.

Stokes, V.J., M.D. Morecroft, and J.I.L. Morison. 2010. Comparison of leaf water use efficiency of oak and sycamore in the canopy over two growing seasons. Trees 24:297-306.

Swoczyna, T., H.M. Kalaji, S. Pietkiewicz, J. Borowski, and E. ZaraśJanuszkiewicz. 2010. Photosynthetic apparatus efficiency of 
eight tree taxa as an indicator of their tolerance to urban environments. Dendrobiology 63:65-75.

Takahashi, S., and N. Murata. 2008. How do environmental stresses accelerate photoinhibition? Trends in Plant Science 13:178-182.

Zotz, G., S. Pepin, and C. Körner. 2005. No down-regulation of leaf photosynthesis in mature forest trees after three years of exposure to elevated $\mathrm{CO}_{2}$. Plant Biology 7:369-374.

Sten Gillner (corresponding author)

Institute of Forest Botany and Forest Zoology, TU Dresden,

Pienner Str. 7, 01737 Tharandt

Germany

[phone] (+49) 35203 38-31354

[fax] (+49) 35203 38-31272

gillner@forst.tu-dresden.de

\section{Sandra Korn}

Institute of Forest Botany and Forest Zoology, TU Dresden, Pienner Str. 7, 01737 Tharandt

Germany

Andreas Roloff

Institute of Forest Botany and Forest Zoology, TU Dresden,

Pienner Str. 7, 01737 Tharandt

Germany

Résumé. Pour les arbres d'alignement, les particularités spécifiques $\mathrm{du}$ sol et la présence d'un microclimat peuvent limiter la croissance, la santé et l'espérance de vie de nombreuses espèces. Plusieurs sites urbains se caractérisent par une grande proportion de surfaces imperméables et de zones pavées résultant en un taux élevé de ruissellement de surface, une faible infiltration dans le sol et l'exposition à des rayonnements solaires multiples. Afin de maintenir les bénéfices écologiques et économiques générés par les arbres d'alignement tout au long des décennies futures, il est essentiel de planter des espèces qui possèdent une tolérance élevée aux contraintes environnementales urbaines.

Des chercheurs ont mesuré les échanges gazeux foliaires d'Acer platanoides, d'Acer pseudoplatanus, de Platanus $\times$ hispanica, de Quercus rubra, et de Tilia platyphyllos afin d'évaluer la conductance stomatique, la transpiration et la photosynthèse nette sur des sites recouverts de surfaces imperméables dans la ville de Dresde en Allemagne.

Les résultats démontrent que le taux déchange gazeux foliaire est nettement plus élevé chez le Platanus $\times$ hispanica et le Quercus rubra, par rapport à l'Acer platanoides et l'Acer pseudoplatanus. Les valeurs moyennes significativement plus élevées de l'efficience de l'utilisation de l'eau par le Platanus $\times$ hispanica et le Quercus rubra, et en particulier les valeurs mesurées durant des périodes spécifiques affichant un déficit de pression de vapeur élevée, indiquent une consommation plus économique d'eau.

Zusammenfassung. Bei Straßenbäumen können die standortspezifischen Boden- und Mikroklimabedingungen bei vielen Arten das Wachstum, die Gesundheit und die Langlebigkeit begrenzen. Viele urbane Standorte sind durch einen hohen Anteil an undurchlässigen Oberflächen und gepflasterten Arealen gekennzeichnet, was zu einer hohen Wasserabflußrate, niedriger Infiltration in den Boden und starken Rückstrahleffekten führt. Um die ökonomischen und ökologischen Vorteile von Straßenbäumen für künftige Jahrzehnte zu erhalten, ist es notwendig, Arten mit einer hohen Toleranz gegenüber stressigen urbanen Umfeldern zu etablieren.
Forscher maßen den Blatt-Gas-Austausch von Acer platanoides, Acer pseudoplatanus, Platanus $\times$ hispanica, Quercus rubra, und Tilia platyphyllos, um die Leitfähigkeit der Stomata, der Transpiration und der Netto-Photosynthese an undurchlässigen Standorten in Dresden, Deutschland zu untersuchen.

Die Ergebnisse zeigen signifikant höhere Blatt-GasaustauschRaten für die Arten Platanus $\times$ hispanica und Quercus rubra, verglichen mit den Arten Acer platanoides und Acer pseudoplatanus. Die signifikant höheren Durchschnittswerte der Wassernutzungseffektivität von Platanus $\times$ hispanica und Quercus rubra, und im besonderen die Werte während der selektierten Periode mit einem hohen Wasserdruckdefizit zeigen einen mehr ökonomischen Wasserverbrauch an.

Resumen. Las condiciones del suelo y el microclima específico del sitio pueden restringir el crecimiento, la salud y la longevidad de muchas especies de árboles urbanos. Muchos sitios urbanos se caracterizan por una cantidad elevada de superficie impermeable y zonas pavimentadas que resulta en una alta tasa de escorrentía superficial, baja infiltración y fuertes efectos de la radiación solar. Para el mantenimiento de los beneficios ecológicos y económicos de los árboles a través de las décadas futuras es esencial establecer especies con una alta tolerancia a los ambientes de estrés urbano.

Los investigadores midieron el intercambio gaseoso foliar de Acer platanoides, Acer pseudoplatanus, Platanus x hispanica, Quercus rubra, y Tilia platyphyllos con el fin de evaluar la conductancia estomática, transpiración y fotosíntesis neta en sitios urbanos impermeables en la ciudad de Dresden, Alemania.

Los resultados muestran valores altos de intercambio de gases para la especie Platanus $\times$ hispanica y Quercus rubra, en comparación con la especie Acer platanoides y Acer pseudoplatanus. Los valores más altos de eficiencia del uso del agua de Platanus $\times$ hispanica y Quercus rubra, y en particular los valores durante los períodos seleccionados con un déficit de presión de vapor alta, indican un consumo de agua más económico. 